\title{
EFFECT OF AIRFLOW PROFILE ON REDUCING HEAT STRESS, ENHANCING AIR DISTRIBUTION AND DILUTING GASEOUS CONCENTRATIONS IN DAIRY BARNS
}

\author{
M. Samer ${ }^{1,2}$
}

\section{ABSTRACT}

Heat stress in dairy cows is one of the leading causes of decreased production and fertility. Increasing air velocity, using ceiling fans, to enhance convective heat transfer and accordingly body heat dissipation is highly required. However, this might have negative effects such as increasing emission mass flux of the harmful gases. Therefore, this study aims at investigating the effect of ceiling fans on the dairy cows, air velocity profiles, and the distribution of gaseous concentrations throughout a naturally ventilated dairy barn. Three air velocity measurements campaigns, with two repetitions each, were carried out during summer season 2010. The air velocity was measured inside the barn using ultrasonic anemometers. The air temperature and humidity were measured using temperature-humidity sensors. The climatic data were recorded by weather station. The concentrations of $\mathrm{CO}_{2}, \mathrm{NH}_{3}, \mathrm{CH}_{4}$, and $\mathrm{N}_{2} \mathrm{O}$ were measured using a multi-gas monitor. The heat stress was estimated by determining the Temperature-Humidity Index (THI). A thermal infrared imaging camera was used to investigate the heat relief from the cows and freestalls under 2 conditions, which were: ceiling fans on and ceiling fans off. The results showed that the implementation of ceiling fans reduced the THI from 79 (significant stress) to 68 (no stress). The average air velocities were 0.98 and $0.59 \mathrm{~m} \mathrm{~s}^{-1}$ as the ceiling fans were "on" and "off", respectively. It was concluded that the ceiling fans have cooling effect, alleviate the heat stress, and enhance the air movement and distribution throughout the barn. However, the ceiling fans indirectly increase the ventilation rates in higher potential then the disguised decrease of the gaseous concentrations, which ultimately results in increasing the gaseous emissions.

\footnotetext{
${ }^{1}$ Assistant Professor, Depart. of Agric. Eng., Faculty of Agriculture, Cairo University, Egypt

${ }^{2}$ Research Scientist, Leibniz Institute for Agric. Eng. Potsdam-Bornim (ATB), Potsdam, Germany
} 
Therefore, a balance must be achieved among the different contradictions: air velocity optimization, heat stress alleviation, air distribution enhancement, and gaseous emissions reduction.

Keywords: Air velocity profiles, Ceiling fans, Dairy barns, Gaseous emissions, Heat stress.

\section{INTRODUCTION}

7 he investigation of airflow profiles in animal buildings is of great importance, where the results of airflow analysis can be

1 implemented to reduce the heat stress that affects the dairy cows and to achieve better air distribution throughout the barn avoiding dead corners where the gaseous concentrations are high and then detrimental for animals and workers.

Bassiouny and Korah (2011) stated that ceiling fans, which increase air velocity, are extensively used to create an indoor breeze, improve the space air distribution, to enhance convective heat transfer and accordingly body heat dissipation, and hence enhance the feeling of comfort. Bartzanas et al. (2007) stated that air velocity measurements incarnate the corner stone for airflow analysis in rural buildings. Bjerg and Sørensen (2008) mentioned that the modern demands of airflow in livestock buildings should be fulfilled, which are: air distribution, control, energy efficiency, and air velocity in the animal occupied zone. Several procedures -which requires air velocity measurements- should be implemented, and they are: determining air velocity at animal level, limiting air velocity in the animal occupied zone, investigating air velocity profiles and turbulences, homogenizing air velocity distribution in the entire barn, determining whether air velocity distribution inside and close to the inlet are similar, homogenizing airflow throughout the whole barn, reducing air velocity at floor level at high ventilations rate without increasing the pressure drop over the inlet.

Snell et al. (2003) stated that the climatic data influence the ventilation rate and the emission. They added that depending on the building design, the ventilation rate could be explained by the climatic values (wind velocity and ambient temperature), where the wind velocity is of central importance for the ventilation. On the other hand, the drawing-off 
emission flux of harmful gases from a naturally ventilated barn is dependent on wind velocity and turbulence fields inside and over the barn envelope (Van Buggenhout et al., 2009; Ngwabie et al., 2009). Pereira et al. (2011) stated that in naturally ventilated cattle houses, emissions of $\mathrm{NH}_{3}, \mathrm{~N}_{2} \mathrm{O}, \mathrm{CO}_{2}$ and $\mathrm{CH}_{4}$ are significantly increased with air temperature.

Morsing et al. (2008) stated that odors and gases emitted from animal houses are strongly related to airflows. Additionally, knowledge of the air profiles inside the dairy barn, the exchange mechanisms between air and the manure surface in the slurry pit, and between air and the soiled surfaces and animals within the building may lead to novel and efficient ways of reducing the odor emission. They hypothesized that the effects on gas emissions are as a consequence of changing airflow patterns and different types of flow in the boundary layer between the slurry and ventilation air. According to Sun et al. (2002), the air velocity profiles show that air moves from lower to upper level, which affects the $\mathrm{NH}_{3}$ distribution in the barn space.

Hatem (1993) cited that, comfortable zone is the range of temperatures, moistures, and air velocities within which animals can live and reach acceptable production levels. Schmidit et al. (1988) reported that, comfort range for dairy cows is between 4.5 and $21{ }^{\circ} \mathrm{C}$. Cows are usually not adversely affected by the cold until the temperature drops to $-15{ }^{\circ} \mathrm{C}$, below this temperature a drop in milk production occurs. Lindley and Whitaker (1996) cited that, the optimum temperatures range from 16 to $18{ }^{\circ} \mathrm{C}$. Stowell (2000) reported that, when temperature is between 5 and $15{ }^{\circ} \mathrm{C}$ the cows are most productive, and when the temperature is between 15 and $25{ }^{\circ} \mathrm{C}$ a small degree loss in production occurs, when the temperature exceed the upper critical temperature $\left(25^{\circ} \mathrm{C}\right)$ a great degree loss in production occurs. Keown and Grant (1999) stated that heat stress in dairy cattle is one of the leading causes of decreased production and fertility. Thus, dairy cattle need mechanical means to reduce heat stress. If the body temperature increases from $38.8{ }^{\circ} \mathrm{C}$ to $39.9{ }^{\circ} \mathrm{C}$ a drop of 2.2 $\mathrm{kg} \mathrm{day}^{-1}$ in milk production occurs. Skin and rectal temperatures and respiration rate increase with the increasing of the temperature. Therefore, installation of cooling system is required. Additionally, 
cooling system efficiency increases by increasing shed height (Hatem et al., 2004a; Hatem et al., 2004b; Hatem et al., 2006).

This paper aims at investigating the effect of ceiling fans on: (1) the dairy cows, (2) the air velocity profiles, and (3) the distribution of gaseous concentrations throughout a naturally ventilated dairy barn.

\section{MATERIALS AND METHODS}

\section{Barn Description}

The measurements were carried out during summer season 2010, in a dairy barn (Fig. 1) located in north-east Germany. The investigated dairy barn is surrounded by several agricultural buildings, except the southern and western sides. Fortunately, the prevailing summer winds are south and south-west winds. The dairy barn was $96 \mathrm{~m}$ long and $34 \mathrm{~m}$ wide. The roof top varied from $4.2 \mathrm{~m}$ at the side to $10.7 \mathrm{~m}$ at the gable top. The internal room volume of the barn amounted to $25,499 \mathrm{~m}^{3}\left(70 \mathrm{~m}^{3} \mathrm{cow}^{-1}\right)$, where the barn is designed to house 364 dairy cows in loose housing system with freestalls. The manure handling system was equipped with winch-drawn manure scrapper. The dairy barn was naturally ventilated by air draft introduced into the building through adjustable curtains in the sidewalls (which were protected by nets), open ridge slot, space boards of the gable walls, and open doors in the gable walls. Three additional ceiling fans were used to enhance the uniformity of air distribution inside the barn. The fans were mounted to the ceiling along the building centerline and had a diameter of $7.2 \mathrm{~m}$ with a maximum discharge of $546,000 \mathrm{~m}^{3} \mathrm{~h}^{-1}$.

\section{Experiments and Instruments}

Three measurements campaigns, with two repetitions each, were carried out during summer season 2010. The experiments of heat stress, air velocity and gaseous concentrations were carried out independently and separately, i.e. they were not timely consistent.

The air velocity (speed and direction) was measured using ultrasonic anemometers (USAs) -at a height of $1.3 \mathrm{~m}$ from floor- in 36 points over the freestalls, and other 3 points over the feeding bunk (Fig. 2). Additionally, there were 2 external measuring points located next to the southern side of the building in order to face the prevailing summer wind. 
The USAs were north oriented. The barn was divided into 6 zones, where the measurements were carried out through a zone separately from the other zones and in 7 measuring points through each zone at the same time. Seven ultrasonic anemometers (USAs) (WindMaster and WindMaster Pro, ultrasonic anemometer, Gill Instruments Limited, Lymington, Hampshire, UK) are used to carry out air velocity measurements in practice barn. Wind software (Wind (c) 2008 Gill Instruments, Version 2324-106, Gill Instruments Limited, Lymington, Hampshire, UK) has been used for configuring the USAs. Using the aforementioned software the technical characteristics of the different anemometers can be specified, which are: baud rate (symbols per second), message output format (uv, or Polar), output rate $(\mathrm{Hz})$, measurement unit $\left(\mathrm{m} \mathrm{s}^{-1}\right)$, alignment (North to spar), resolution, sonic temperature display $\left(\mathrm{T},{ }^{\circ} \mathrm{C}\right)$, and analogue output mode.

The concentrations of $\mathrm{CO}_{2}, \mathrm{NH}_{3}, \mathrm{CH}_{4}$, and $\mathrm{N}_{2} \mathrm{O}$ were continuously measured, using a multi-gas monitor (INNOVA 1312, Innova AirTech Instruments, Ballerup, Denmark), inside the barn at eight uniformly distributed sampling points and outside the barn at four points. The air temperature and humidity were measured inside and outside the building using 6 temperature-humidity sensors/loggers (Comark Diligence EV N2003, Comark Limited, Hertfordshire, England), where these sensors were positioned at four symmetric locations inside the building and 2 locations outside on the long side walls. The external wind velocity was measured and recorded by a weather station (DALOS 515c-M, F\&C Forschungstechnik \& Computersysteme $\mathrm{GmbH}$, Guelzow, Germany) located near the dairy barn ( $70 \mathrm{~m}$ south-east of the barn.

The heat stress was estimated by determining the Temperature-Humidity Index (THI) according to the following equation (CIGR, 2002):

$$
\mathrm{THI}=0.8 \times \mathrm{T}_{\mathrm{i}}+\left[\left(\mathrm{RH}_{\mathrm{i}} / 100\right) \times\left(\mathrm{T}_{\mathrm{i}}-14.3\right)\right]+46.4
$$

Where, $\mathrm{T}_{\mathrm{i}}$ is the indoor air temperature $\left({ }^{\circ} \mathrm{C}\right)$ and $\mathrm{RH}_{\mathrm{i}}$ is the indoor relative humidity (\%). If THI less than 72 there is no stress, between 73 and 77 there is mild stress, between 78 and 88 there is significant stress, between 89 and 99 there is severe stress, if THI exceeds 99 possible death occurs (Keown and Grant, 1999). A Thermal Infrared Imaging Camera (Fluke Ti9, Software Fluke SmartView ${ }^{\circledR}$, Everett, Washington, 
USA) was used to investigate the heat relief from the cows and the freestalls under 2 conditions: (a) ceiling fans on, and (b) ceiling fans off.
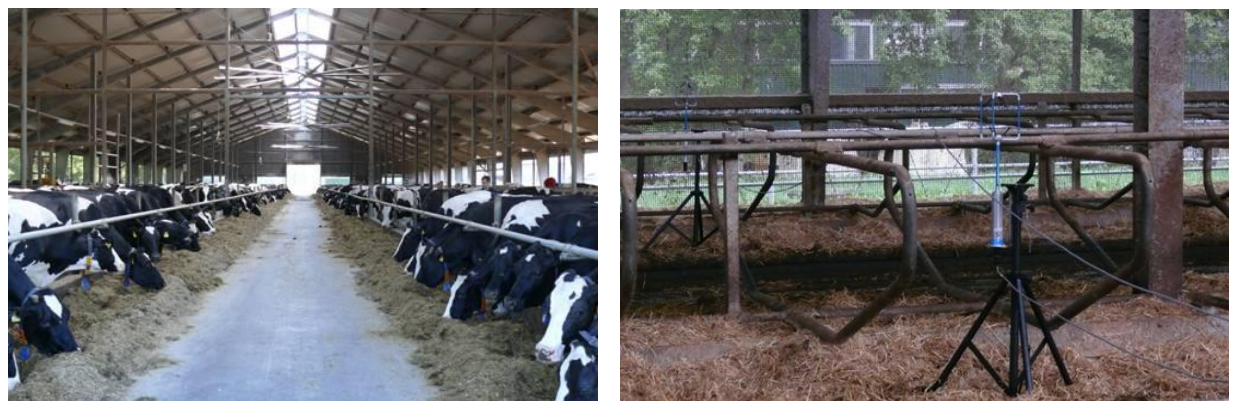

Fig. 1: Internal view of the barn showing the ceiling fans (left) and used ultrasonic anemometer (right).

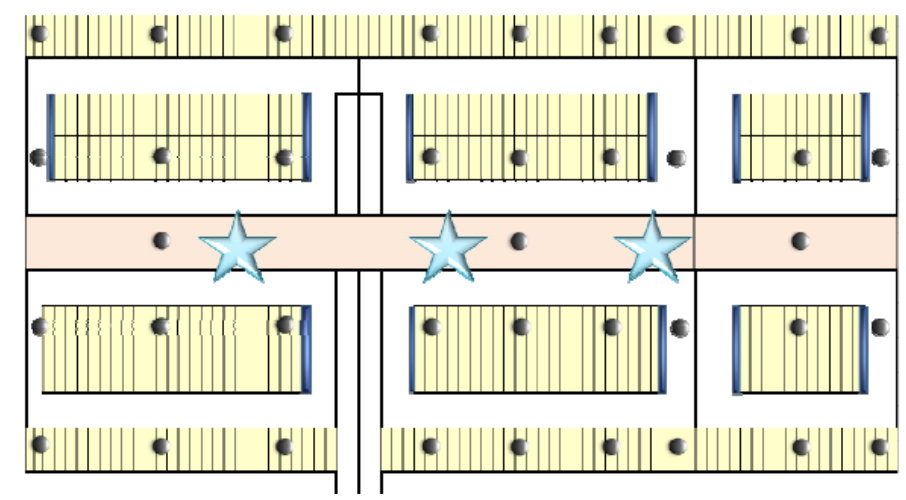

Fig. 2: Plan view of the barn showing measuring points of air velocity, where the stars represent the ceiling fans.

\section{RESULTS AND DISCUSSION}

\section{Climatic and Microclimatic Conditions}

The outdoor climatic conditions are presented in Table 1. The outdoor temperature ranged between $27.5{ }^{\circ} \mathrm{C}$ and $29.3{ }^{\circ} \mathrm{C}$ during the investigations. The indoor temperature ranged between $30.2^{\circ} \mathrm{C}$ and 32.9 ${ }^{\circ} \mathrm{C}$ during all investigations as the ceiling fans were off. The indoor temperature ranged between $24.5{ }^{\circ} \mathrm{C}$ and $28.7{ }^{\circ} \mathrm{C}$ during all investigations as the ceiling fans were on. The outdoor relative humidity ranged between $44.9 \%$ and $68.7 \%$ during the investigations. The indoor relative humidity ranged between $52.3 \%$ and $72.6 \%$ during all investigation periods. The wind velocity (direction and speed) largely 
fluctuated; the wind direction ranged between $239^{\circ}$ and $249^{\circ}$ from north, and the wind speed varied from 1.4 to $3.12 \mathrm{~m} \mathrm{~s}^{-1}$ during the experiments. Figure 3 shows average wind speed and direction from the environment adjacent to the investigated barn.

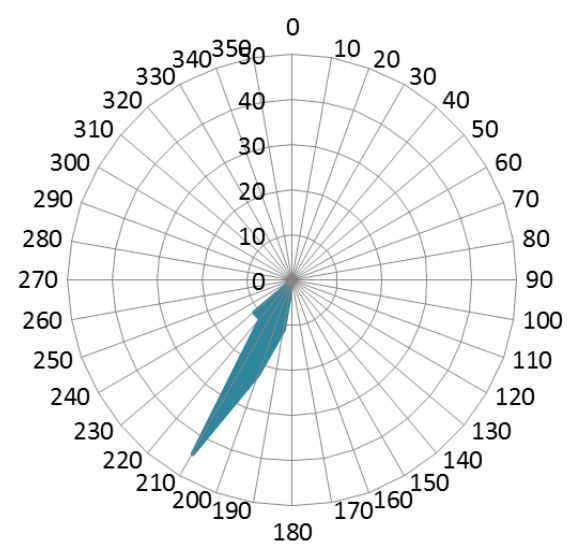

Fig. 3: Wind rose drawn using the climatic data acquired from the on-site weather station.

Table 1: Average outdoor climatic data.

\begin{tabular}{lcccccc}
\hline \multicolumn{1}{c}{ Experiment } & 1 & 2 & 3 & 4 & 5 & 6 \\
\hline Wind Direction $\left({ }^{\circ}\right)$ & 239 & 239 & 246 & 239 & 239 & 246 \\
Wind Velocity $\left(\mathrm{m} \mathrm{s}^{-1}\right)$ & 2.20 & 1.40 & 1.62 & 1.75 & 1.66 & 3.12 \\
Temperature $\left({ }^{\circ} \mathrm{C}\right)$ & 28.0 & 29.3 & 28.9 & 28.4 & 28.7 & 27.5 \\
Relative Humidity $(\%)$ & 52.1 & 68.7 & 65.3 & 58.4 & 62.9 & 44.9 \\
\hline
\end{tabular}

\section{Heat Stress}

Figure 4 shows the thermal infrared images of not occupied freestalls (a and c) and occupied freestalls (b and d), where images (a) and (b) were taken as the ceiling fans were on which decreased the temperature to 24.5 ${ }^{\circ} \mathrm{C}$, and images (c) and (d) were taken as the ceiling fans were off which increased the temperature to $28.7{ }^{\circ} \mathrm{C}$. Hence, the implementation of cooling fans enhances the animal microclimate. Additionally, the fans 
cool the not occupied freestalls which allow cow comfort when the cow decides to lay down in the freestall.

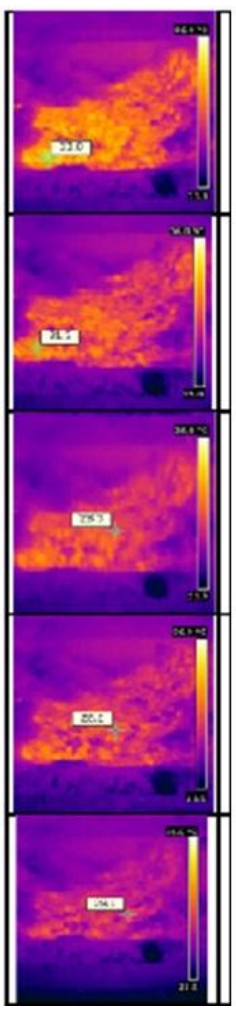

(a)

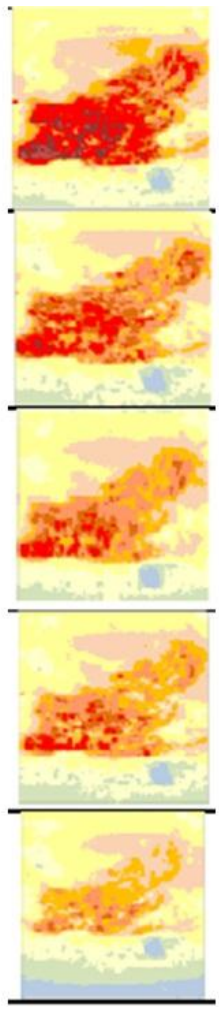

(b)

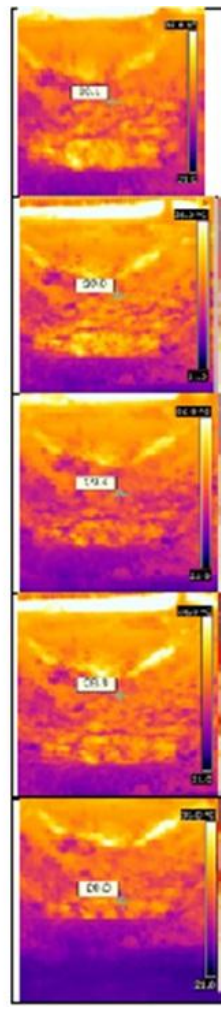

(c)

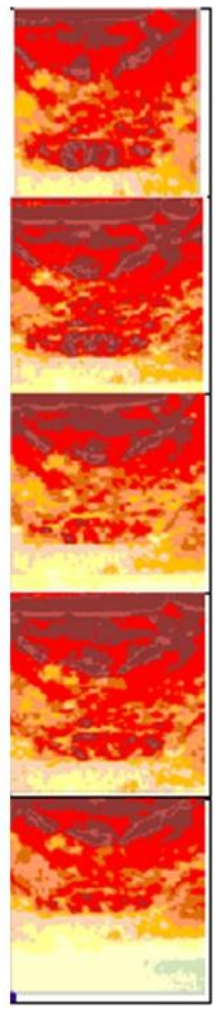

(d)

Fig. 4: Thermal infrared images, where: (a) represents a not occupied freestall as the ceiling fans were on, (b) is an occupied freestall as the ceiling fans were on, (c) represents a not occupied freestall as the ceiling fans were off, and (d) represents an occupied freestall as the ceiling fans were off.

Figure 5 shows the average values of the THI during the different measurements campaigns, where: the black curve represents the THI, the yellow line designates the alert phase (mild stress), red line indicates the danger phase (significant stress), and the dark red shows the emergency phase (severe stress). The green line differentiates between the measurements performed as the ceiling fans were on (under the green line) and the measurements performed as the ceiling fans were off (above 
the green line). The experiments were numbered from 1 to 6 . An unexpected shutting down temperature-humidity sensors occurred between experiment 5 and 6 .

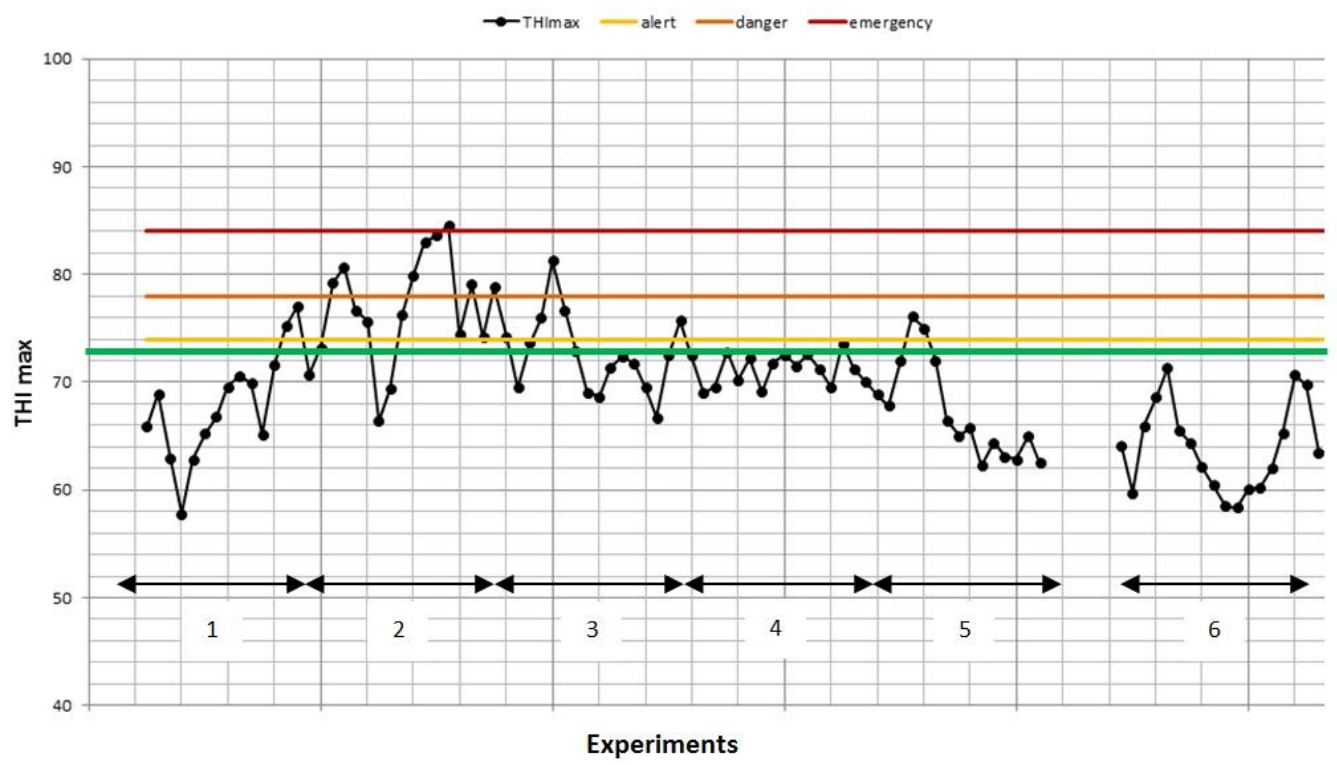

Fig. 5: THI during the different experiments.

The experiments 1, 4, 5 and 6 were carried out as the ceiling fans were on; consequently the THI fell down. On the other hand, the experiments 2 and 3 were carried out as the ceiling fans were off; subsequently the THI rose up. It was not possible to alternately carry out the experiments due to the farm management system and some technical inconveniences. The results (Figs 4 and 5) show that the implementation of ceiling fans reduced the average value of the THI from 79 (significant stress) to 68 (no stress).These results agree with those of Hatem et al. (2004a,b), who stated that the air temperature and the THI decrease when the air velocity near the cow increases. In the present study, the air velocity near the cows was increased using the ceiling fans which acted as cooling fans for the dairy cows, and then reduced the THI from the danger/emergency phase to no stress phase. 


\section{Airflow Profiles}

Airflow patterns in livestock buildings influence the distribution of air temperature, gas concentrations, and the release of gases from manure. Air velocity measurements have been widely used for airflow pattern measurements. To realize an efficient control of the biological response, continuous monitoring, prediction, and control of the micro-environment to variations of control inputs is required (Berckmans and Vranken, 2006). Therefore, the air profiles were investigated and airflows were analyzed in full-scale barn in the present study.

Table 2 shows the results of wind profile measurements, where the results are averages of 2 repetitions for each measurements campaign, and 39 velocity readings per repetition. Additionally, Table 2 shows the external wind velocity which was recorded by the weather station. Figure 6 shows the air velocity profiles at the different measuring points as the ceiling fans were off. On the other hand, Figure 7 shows the air velocity profiles at the different measuring points as the ceiling fans were on.

Table 2: Results of airflow profile measurements.

\begin{tabular}{cccc}
\hline \multirow{2}{*}{$\begin{array}{c}\text { Measurements } \\
\text { Campaign }\end{array}$} & \multicolumn{3}{c}{ Average Air Velocity, $\mathrm{m} \mathrm{s}^{-1}$} \\
\cline { 2 - 3 } & \multicolumn{2}{c}{ Inside the Barn } & External Wind \\
\cline { 2 - 3 } 1 & 0.51 & 0.92 & 1.51 \\
2 & 0.75 & 1.07 & 2.61 \\
3 & 0.51 & 0.95 & 2.67 \\
\hline
\end{tabular}

Generally, the values recorded by the measuring points located in zones near to, or under the ceiling fans were the highest values and more stable than the fluctuating values away from the ceiling fans (Fig. 7). Furthermore, the measuring points those are located near to the open southern side of the barn, which is the windward side of the barn that faces the prevailing summer wind, recorded high values of air speed with 
fluctuations. On the other hand, the measuring points located near to the northern side of the barn, which is the leeward side of the barn, recorded lower values of air speed. The ceiling fans enhanced the air movement and distribution throughout the barn, which has been noticed by comparing the air profiles in Figures 6 and 7 in conjunction with Table 2. These results agree with those of Bassiouny and Korah (2011).

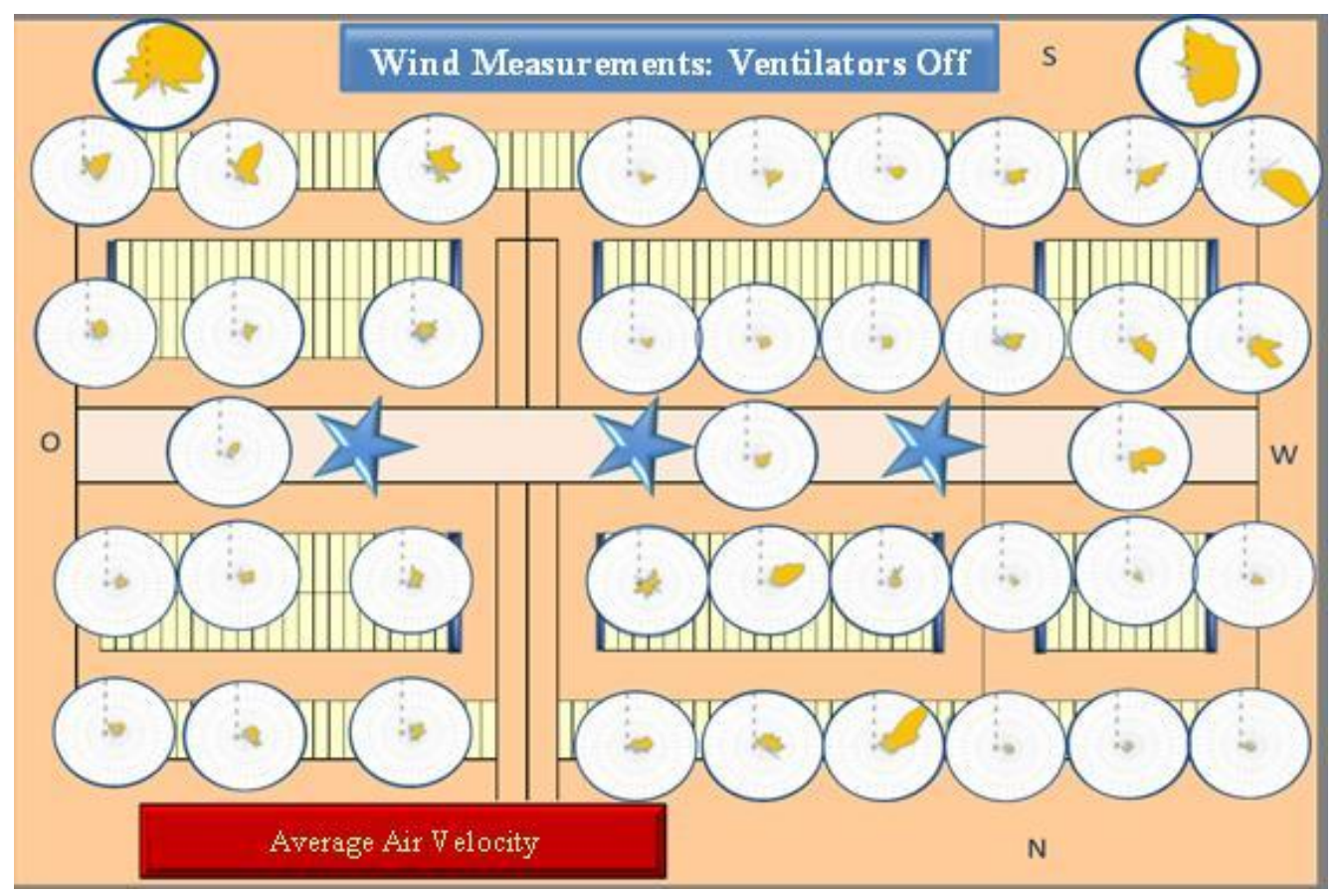

Fig. 6: Average air velocity and wind direction as the fans were off. The stars represent the ceiling fans.

\section{Gaseous Concentrations}

Figure 8 shows the concentrations of the different gases throughout the different experiments. The experiments 1, 3, 6 and 7 were carried out as the ceiling fans were off. The experiments 2, 4 and 5 were carried out as the ceiling fans were on. It must be indicated that the experiments of gaseous concentrations are not timely consistent with those of heat stress. An unexpected shutting down gas monitor during experiment 3 occurred. 


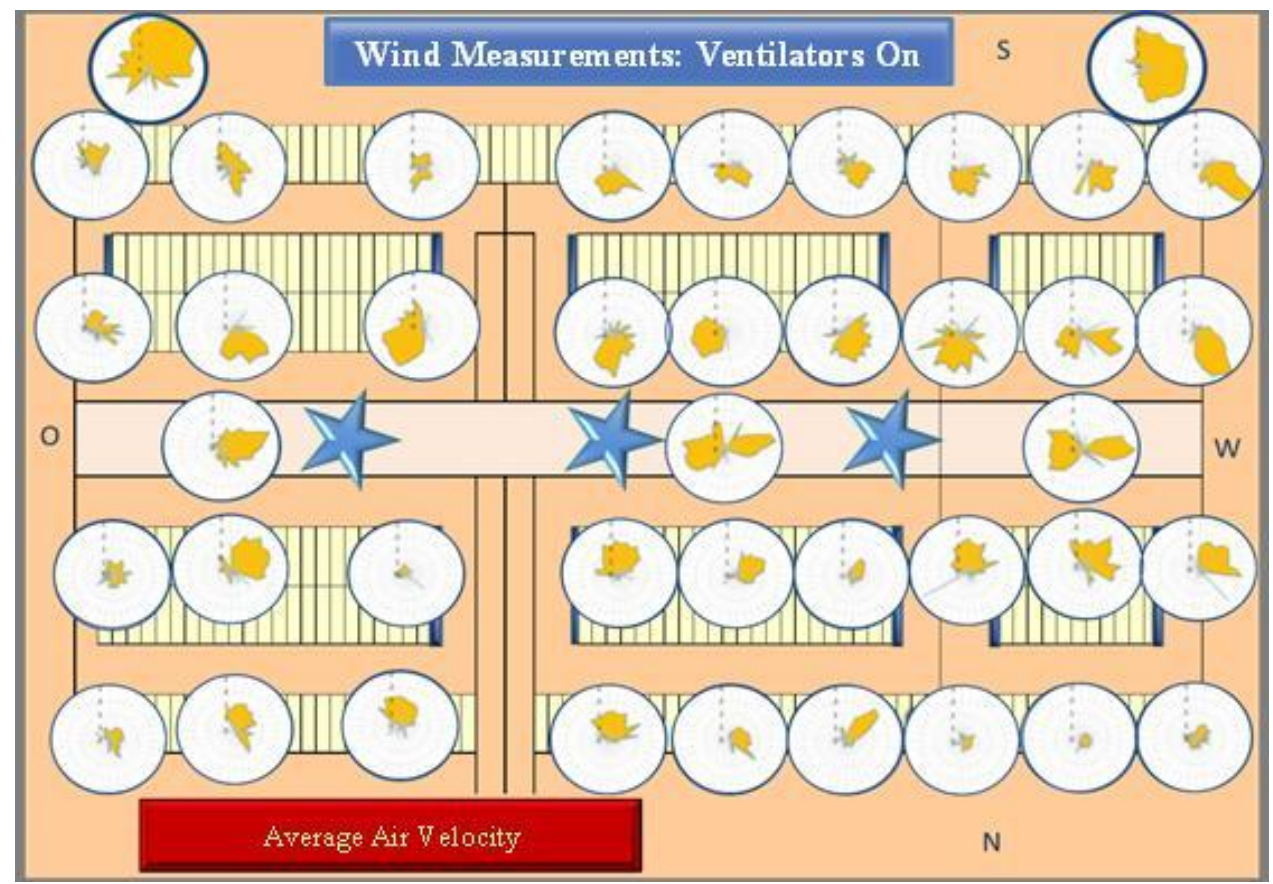

Fig. 7: Average air velocity and wind direction as the fans were on. The stars represent the ceiling fans.

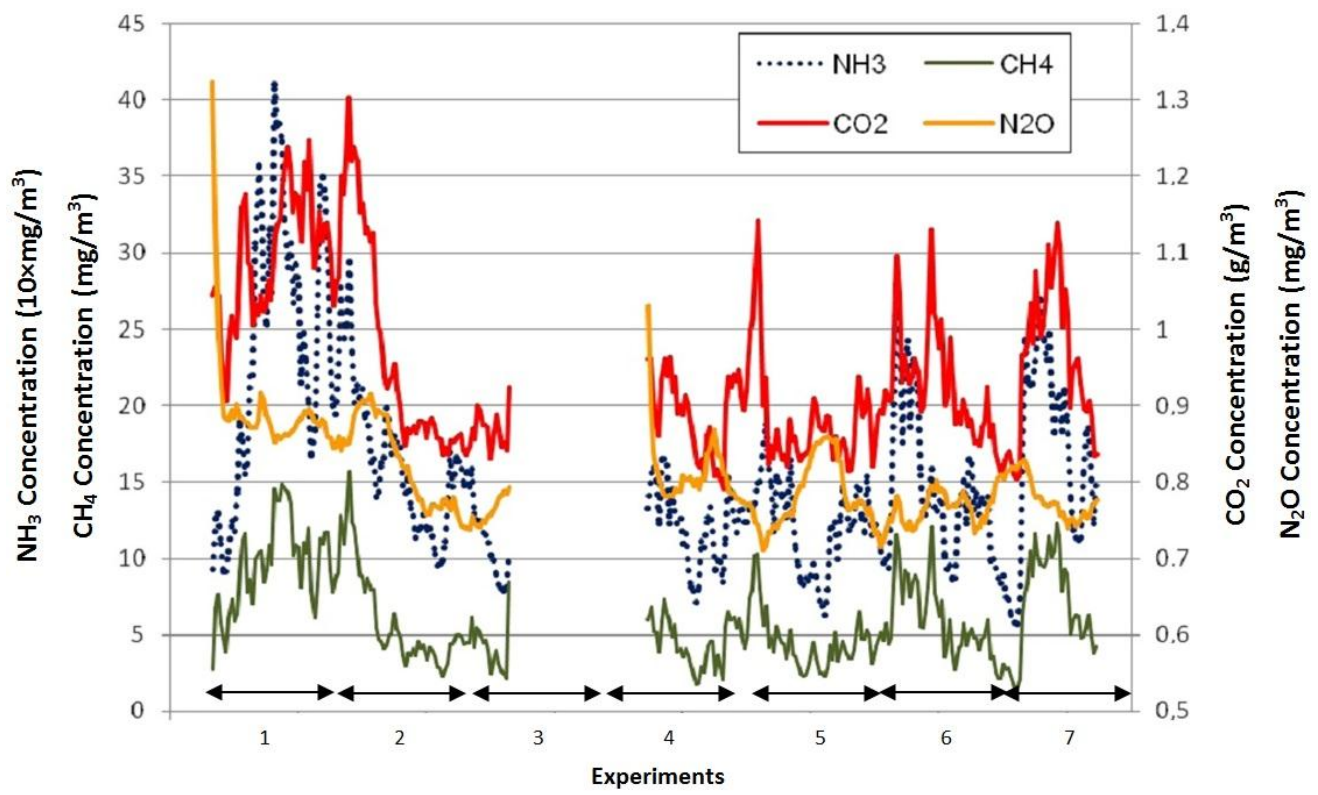

Fig. 8: Gaseous concentrations during the different experiments. 
The results (Fig. 8) show that the concentrations of the gases increase when the ceiling fans were off, and decrease when the ceiling fans were on. This is due to the enhanced air distribution when operating the ceiling fans as shown in Figure 7. This is much clearer in Figure 9 which represents the ammonia concentrations through three experiments, where: experiment 1 was performed as the ceiling fans were off; experiment 2 was performed as the ceiling fans were on, and experiment 3 was performed as the ceiling fan was on with low rotational speed. This led to wrong conclusions that: (1) the gaseous emissions increase when the ceiling fans were off and decrease when the ceiling fans were on, and (2) the gaseous emissions are indirectly proportional to the rotational speed of the ceiling fan.

However, this does not reveal the facts, where the gaseous concentrations are disguised. In other words, when the ceiling fans operates they increase air velocity which increases in turn the emission mass flux that should increase the gaseous concentrations, but the high air velocity and accordingly the enhanced air distribution throughout the barn disguised these gaseous concentrations. In order to better understand this phenomenon, the gaseous concentrations $\left(\mathrm{mg} / \mathrm{m}^{3}\right)$ are multiplied by the ventilation rates $\left(\mathrm{m}^{3} / \mathrm{h}\right)$ to get the gaseous emissions $(\mathrm{mg} / \mathrm{h})$. The higher the air velocity (ceiling fans), the higher is the ventilation rate. Even though the barn is naturally ventilated, the ceiling fans accelerate the process of natural ventilation. Precisely, the ceiling fans indirectly increase the ventilation rates in higher potential then the disguised decrease of the gaseous concentrations, which ultimately results in increasing the gaseous emissions.

Generally, the ceiling fans enhanced the air distribution throughout the barn and increased the air velocity near the cows which emphasize that the ceiling fans had cooling effects and relatively reduced the ambient air temperature; consequently, the heat stress (THI) decreased. However the emissions mass flux of the different gases increases with increasing the air velocity (Van Buggenhout et al., 2009; Ngwabie et al., 2009). 


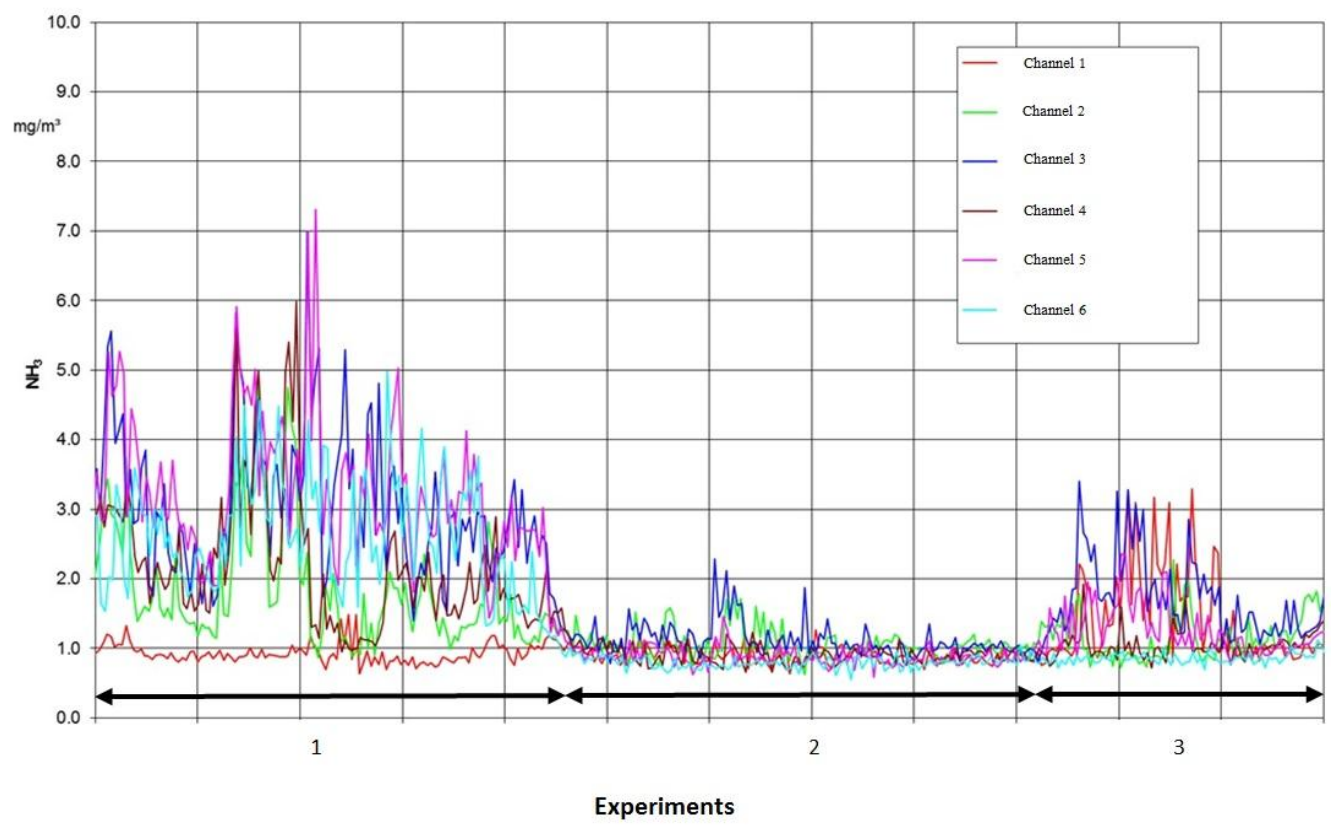

Fig. 9: Ammonia concentrations through different experiments.

Bjorneberg et al. (2009) stated that low emission values can only be achieved by decreasing air velocity and temperature near the emission source, and minimizing air volumetric flow rates throughout the livestock buildings. A conflict is that ceiling fans, which increase air velocity, are extensively used to create an indoor breeze, improve the space air distribution, to enhance convective heat transfer and accordingly body heat dissipation, and hence enhance the feeling of comfort (Bassiouny and Korah, 2011). Therefore, more investigations are required to achieve a balance among the following contradictions: (1) air velocity optimization, (2) heat stress alleviation, (3) air distribution enhancement, and (4) gaseous emissions reduction. In order to achieve this balance, the future investigations should focus on determining the optimal air velocity and then the optimal fan discharge, dimensions, and number for a determined number of cows and barn specifications.

The results of the present study agree with Morsing et al. (2008) who hypothesized that airflow patterns affect the gas emission, and the type of flow in the boundary layer influences gas transport from the slurry to the 
ventilation air. Additionally, the results agree with Blanes-Vidal et al., 2007 as well as Gay et al., 2003 who stated that low emissions can only be achieved by controlling several factors, thereof decreasing air velocity near the source, and minimizing air volumetric flow rates throughout the livestock building.

Further investigations are also required to study the different combinations of the influencing factors which are: $\mathrm{pH}$-value of the manure, air temperature, air velocity, and the contact area between the ventilation air and slurry. Owing to the fact that the higher the temperature and the higher the $\mathrm{pH}$-value, the higher the emission potential of $\mathrm{NH}_{3}$ which is released due mass transfer from $\mathrm{NH}_{3}$ solved in the liquid manure to $\mathrm{NH}_{3}$ in the air. The main factors that accelerate this process are: high temperature, high air velocity, high turbulence of the air stream, high airflow rate, high ventilation rate, size of the emitting surface, and high $\mathrm{pH}$-value of manure.

\section{CONCLUSIONS}

Airflow patterns in dairy barns influence the air distribution and then the air temperature (heat stress) and the release of gases from manure, i.e. the gaseous concentrations throughout the barn. The air velocity measurements can be implemented to investigate the airflow patterns and to analyze the airflows through the different zones of the barn. The air profiles can be then used to interpret the effects of air velocity on the distribution of harmful gases in the barn space. According to the results of the present study, it can be concluded that:

1. The implementation of ceiling fans alleviates the heat stress.

2. The ceiling fans have cooling effect and help the cows to dissipate heat from their bodies.

3. The ceiling fans enhance the air movement and distribution throughout the barn. 
4. The zones near to, or under the ceiling fans have the highest values and are more stable than the fluctuating values away from the ceiling fans.

5. The ceiling fans indirectly increase the ventilation rates in higher potential then the disguised decrease of the gaseous concentrations, which ultimately results in increasing the gaseous emissions.

6. A balance must be achieved among the different contradictions: air velocity optimization, heat stress alleviation, air distribution enhancement, and gaseous emissions reduction.

7. The optimal air velocity must be determined by identifying the optimal fan discharge, dimensions, and number for a determined number of cows and barn specifications.

\section{Acknowledgements}

The author would like to acknowledge the Department of Engineering for Livestock Management at the Leibniz Institute for Agricultural Engineering Potsdam-Bornim (ATB) in Germany, for the technical and logistical support during the measurements campaigns. Furthermore, the author gratefully acknowledges the assistance of the Institute for Animal Production, State Institute for Agriculture and Fishery MV, Dummerstorf, Germany.

\section{REFERENCES}

Bartzanas, T., Kittas, C., Sapounas, A.A., and Nikita-Martzopoulou, C. (2007). Analysis of airflow through experimental rural buildings: sensitivity to turbulence models. Biosystems Engineering, Vol. 97: 229-239.

Bassiouny, R., and Korah, N.S. (2011). Studying the features of air flow induced by a room ceiling-fan. Energy and Buildings, Vol. 43(8): 1913-1918. 
Berckmans, D., and Vranken, E. (2006). Monitoring, prediction, and control of the microenvironment. In: Munack, A. (Ed.), CIGR Handbook of Agricultural Engineering, Volume VI: Information Technology. ASAE, St. Joseph, MI, USA, pp. 383-401.

Bjerg, B., and Sørensen, L.C. (2008). Numerical simulation of airflow in livestock buildings with radial inlet. Agric. Eng. Int.: CIGR Journal BC 06015 .

Bjorneberg, D.L., Leytem, A.B., Westermann, D.T., Griffiths, P.R., Shao, L., and Pollard, M.J. (2009). Measurements of atmospheric ammonia, methane, and nitrous oxide at a concentrated dairy production facility in southern Idaho using open-path FTIR spectrometry. Transactions of the ASABE, 52: 1749-1756.

Blanes-Vidal, V., Topper, P.A., and Wheeler, E.F., (2007). Validation of ammonia emissions from dairy cow manure estimated with a nonsteady-state, recirculation flux chamber with whole building emissions. Transactions of the ASABE, 50: 633-640.

CIGR. (2002). Climatization of Animal Houses. Editors: Pedersen, S.; Sallvik, K. Working Group Report on: Heat and Moisture Production at Animal and House Level. Published by DIAS, Denmark. www.agrsci.dk/jbt/spe. ISBN 87-88976-60-2.

Gay, S.W., Schmidt, D.R., Clanton, C.J., Janni, K.A., Jacobson, L.D., and Weisberg, S. (2003). Odor, total reduced sulfur, and ammonia emissions from animal housing facilities and manure storage units in Minnesota. Transactions of the ASABE, 19: 347-360.

Hatem, M. H. (1993). Theory of Structures and Agricultural Buildings and Environmental Control. $2^{\text {nd }}$ ed. Cairo, Egypt: Cairo University, Faculty of Agriculture. 
Hatem, M.H., R.R. Sadek, and Samer, M. (2006). Effects of shed height and orientation on dairy cows' microclimate, cooling system efficiency and milk productivity. Proceedings of the $16^{\text {th }}$ CIGR World Congress, 413-414. Düsseldorf, Germany: VDI Verlag.

Hatem, M.H., R.R. Sadek, and Samer, M. (2004a). Shed height effect on dairy cows microclimate. Misr J. Ag. Eng., Vol. 21 (2): 289 - 304.

Hatem, M.H., R.R. Sadek, and Samer, M. (2004b). Cooling, shed height and shed orientation affecting dairy cows microclimate. Misr J. Ag. Eng., Vol. 21 (3): 714 - 726.

Keown, J.F., and Grant, R.J. (1999). How to Reduce Heat Stress in Dairy Cattle. University of Missouri-Columbia, USA.

Lindley, J.A., and Whitaker, J.H. (1996). Agricultural Buildings and Structures. ASAE, St. Joseph, Michigan, USA.

Morsing, S., Strøm, J.S., Zhang, G., and Kai, P. (2008). Scale model experiments to determine the effects of internal airflow and floor design on gaseous emissions from animal houses. Biosystems Engineering, Vol. 99: 99 - 104.

Ngwabie, N.M., Jeppsson, K.-H., Nimmermark, S., Swensson, C., and Gustafsson, G. (2009). Multi-location measurements of greenhouse gases and emission rates of methane and ammonia from a naturally-ventilated barn for dairy cows. Biosystems Engineering, 103: 68-77.

Pereira, J., Fangueiro, D., Misselbrook, T., Chadwick, D., Coutinho, J., and Trindade, H. (2011). Ammonia and greenhouse gas emissions from slatted and solid floors in dairy cattle houses: A scale model study. Biosystems Engineering, 109: 148-157. 
Schmidit, G.H., Van Vleck, L.D., and Hutjens, M.F. (1988). Dairy Cattle Housing, p. 428-444. In: Principles of Dairy Science. $2^{\text {nd }}$ Edition. Prentice Hall, U.S.A.

Snell, H.G.J., Seipelt, F., and van den Weghe, H.F.A. (2003). Ventilation rates and gaseous emissions from naturally ventilated dairy houses. Biosystems Engineering, Vol. 86: 67-73.

Stowell, R.R. (2000). Heat Stress Relief and Supplemental Cooling. Proceedings of Dairy Housing and Equipment Systems, NRAES, Ithaca, New York, p. 175-185.

Sun, H., Stowell, R.R., Keener, H.M., and Michel, Jr. F.C. (2002). Twodimensional computational fluid dynamics (CFD) modeling of air velocity and ammonia distribution in a High-Rise ${ }^{\mathrm{TM}}$ hog building. Transactions of the ASAE, Vol. 45(5): 1559-1568.

van Buggenhout, S., van Brecht, A., Eren Özcan, S., Vranken, E., van Malcot, W., and Berckmans, D. (2009). Influence of sampling positions on accuracy of tracer gas measurements in ventilated spaces. Biosystems Engineering, 104: 216-223.

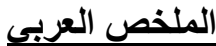

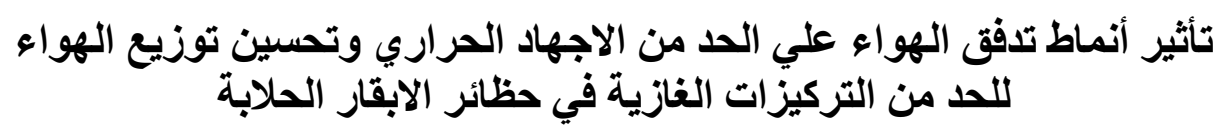

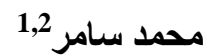

الإجهاد الحراري في الأبقار المنتجة للألبان هي واحدة من الأسباب الرئيسية لانخفاض الإنتاج

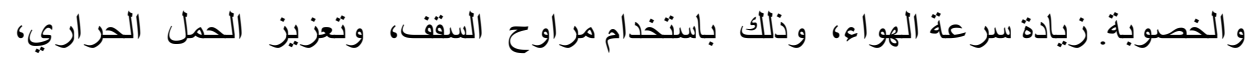

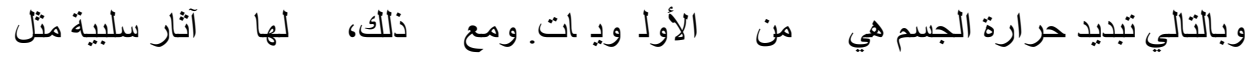

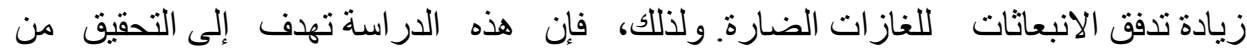

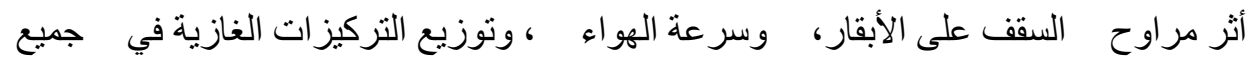

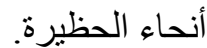

1مدرس بقسم الهندسة الزراعية، كلية الزراعة، جامعة بامعة القاهرة 2باحث بمعهد لايبنيتز للهندة الزينة الزراعية، بوتسدام، ألمانيا 


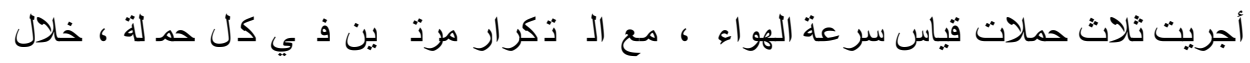

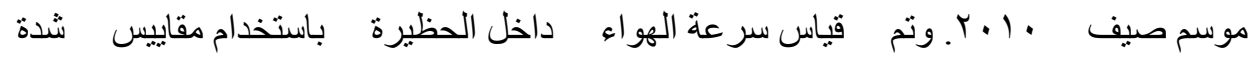

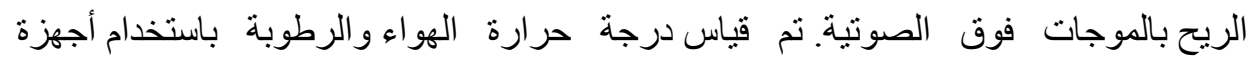

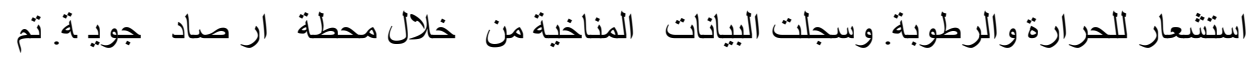
قياس تركيز N

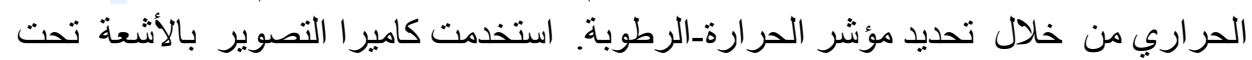

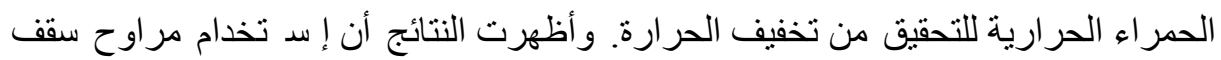

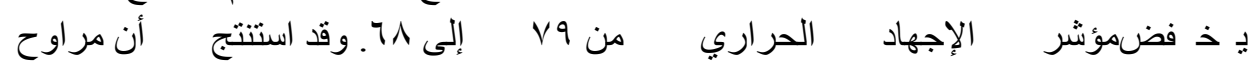

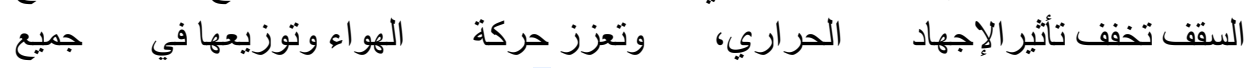

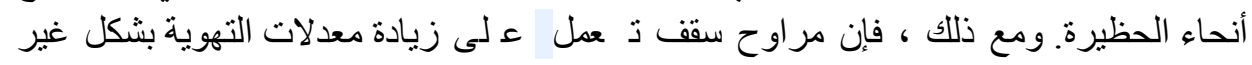

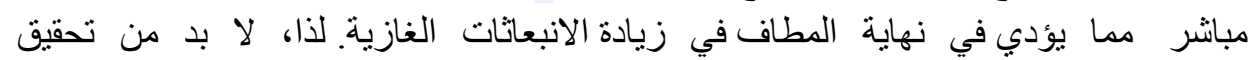

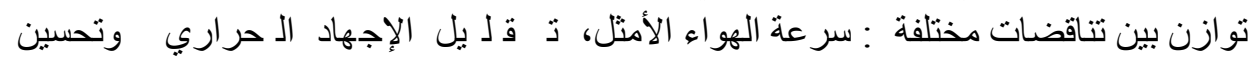
توزيع الهو اء، و الحد من الانبعاثات الغازية.

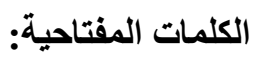

الإجهاد الـ حراري، سرعة الـ هواء،فقسلا حوارم, الانبعاثات الغازية، مباني الأبقار الحلابة. 